\title{
Reformas Penais na Colômbia (1830-1940): Ideologias Políticas, Organização do Poder e Valores Sociais
}

\author{
Aura Helena Peñas Felizzola ${ }^{1}$ \\ Gláucio Ary Dillon Soares ${ }^{2}$ \\ ${ }^{1}$ Professora da Universidad Santo Tomás. Bogotá, Colômbia. \\ E-mail: aurahelena77@gmail.com, https:/ / orcid.org/0000-0003-4768-2224 \\ ${ }^{2}$ Pesquisador associado do Instituto de Estudos Sociais e Políticos (IESP) da Universidade do Estado do \\ Rio de Janeiro. Rio de Janeiro, RJ. Brasil. \\ E-mail: soares.glaucio@gmail.com, https:/ / orcid.org/0000-0003-4571-9054
}

\section{INTRODUÇÃO}

$\mathrm{O}$ processo de negociação de paz entre o governo colombiano e a Fuerza Armada Revolucionaria Colombiana (FARC), suscitou amplo debate sobre as penas que deveriam ser aplicadas a membros da guerrilha (Colômbia, Gobierno y Farc, 2016). O debate sobre a possibilidade de anistias, a duração de penas privativas da liberdade e outras sanções penais, dividiu a institucionalidade pública, as organizações de direitos humanos, e a percepção dos cidadãos. Constantemente, diferentes setores da opinião pública, muitas vezes ideologicamente opostos, clamam por reformas penais como resposta às demandas de segurança. São cada vez mais frequentes os recursos jornalísticos (e políticos) de publicar declarações das vítimas de crimes, e de culpar a legislação e os funcionários dos órgãos da justiça pela percepção de aumento da criminalidade.

Aparentemente, os motores das reformas penais são as pressões de indivíduos e de setores da opinião pública, que defendem seus direitos e interesses, frente a fatos e sujeitos criminais que os vulneram. Porém, quando se revisam as teorias da punição, e principalmente quando se analisa empiricamente as reformas penais em perspectiva histórica, as respostas se mostram mais complexas. Este artigo foca-se na análise das punições previstas em quatro códigos penais colombianos, adotados nos anos de 1837, 1873, 1890 e $1936^{1}$.

DADOS, Rio de Janeiro, vol.63(2): e20180151, 2020. 
A análise permite evidenciar as diferenças na severidade das punições entre governos de ideologia política liberal e conservadora. Ilustra-se a tese que a penalização objetiva, ou punition in the books, dirige-se a impor ideias de ordem social ${ }^{2}$, e que essas ideias derivam sobretudo da ideologia do regime político. Porém, a hierarquia dos valores sociais tutelados, tanto coletivos quanto individuais, tende a permanecer estável no longo prazo, sendo independente do regime político.

Nessa pesquisa o direito penal é definido como um modelo de ordem social (Douglas, 1998) ${ }^{3}$. Não se interessa pelos efeitos das leis penais na conduta desviada (prevenção geral ou prevenção especial) e, portanto, não se insere no âmbito da criminologia etiológica, preocupada com as causas da criminalidade e os possíveis mecanismos de controle da delinquência. A pesquisa se aloca no campo da sociologia do direito penal e se interessa pela chamada punition in the books, na tradição jurídica anglo-saxã, ou criminalização primária, na criminologia continental (Baratta, 2004), que consiste na definição legal das condutas criminais e castigadas penalmente. No sistema jurídico colombiano, a definição das condutas classificadas como socialmente lesivas se faz através de códigos penais e leis penais ${ }^{4}$.

O artigo está dividido em quatro seções. Primeiramente, são identificados na literatura os principais motores das reformas dos sistemas de punição formal. Em segundo momento, é detalhada a metodologia da pesquisa. Em seguida, são apresentados os resultados da análise empírica. Por fim, são feitas as considerações finais sobre os principais motores das reformas aos códigos penais.

\section{A PUNIÇÃO FORMAL NA TEORIA SOCIAL}

A punição tem sido identificada pelos especialistas como uma das áreas mais estudadas e desenvolvidas da teoria social, considerando o nível de suas elaborações e de seus estudiosos, desde Bentham e Tocqueville, passando por Durkheim, Foucault, Rusche e Kirchheimer, até pensadores sociais atuais, como David Garland e Loïc Wacquant (Whitman, 2005).

O castigo institucionalizado é um universo de estudo que toca várias disciplinas, entre as quais estão a antropologia (Malinowsky, 1964), a sociologia clássica (Durkheim, 2013; Marx, 1945, 1946; Weber, 1997), a teoria social (Foucault, 1995, 1997, 2002; Luhmann, 2005), a teoria 
penal (Jakobs e Cancio Meliá, 2003) e a criminologia contemporânea (Garland, 2006, 2007). De onde vem todo este interesse da teoria social e penal pela punição? Desde uma perspectiva antropológica, Mary Douglas (1998) nota que a teoria sociológica da rejeição é mais plausível que a do valor. As condutas que uma sociedade rejeita e pune como transgressões da ordem provavelmente dão uma ideia mais precisa do que os indivíduos pensam, da mesma forma que

os restos de comida revelam dados mais concretos sobre a dieta alimentar do que respostas a questionários. A teoria do desvio social constitui outro tipo de abordagem indireta à sociologia cognitiva. Ela examina os refugos (Douglas, 1998:82).

Os participantes de uma prática social, ao serem questionados sobre seus valores, podem realizar excessivas interpretações sobre o tipo de comportamento visto mais positivamente por eles. Em contraste, o estudo das aversões sociais proporciona evidências mais claras, pois as regras para evitar ser castigado por uma conduta censurada, os tipos de punições, e os mecanismos de purificação, são bem conhecidos por todos.

Variados instrumentos conceituais concebidos pela big theory têm a punição como objeto central ou como uma das variáveis relevantes na compreensão das sociedades modernas. O conceito genérico "punição" faz referência "ao tecido de leis, procedimentos, discursos, representações e instituições que integram o âmbito penal", o qual envolve:

[M] arcos discursivos de autoridade e condena, processos rituais de imposição do castigo, um repertório de sanções penais, instituições e órgãos para o cumprimento das sanções, e uma retórica de símbolos, figuras e imagens por meio das quais o processo penal se representa frente a diversos estratos da sociedade (Garland, 2006:33).

O castigo institucionalizado compõe-se, então, de fases ou dimensões inter-relacionadas, porém distintas, sejam elas: 1) a criação de leis penais ("criminalização primária"); 2) a acusação e a condenação; e 3) a execução da pena. A teoria social da punição reflete essa diversidade de objetos de estudo. No tocante à punição formal (1), Durkheim, os marxistas, Merton (1938) e Elias (1994) esclarecem os motores morais e ideológicos das reformas penais. Rusche e Kirchheimer 
(2004) e Foucault $(2002,1997,1995)$, explicam facetas específicas das mudanças históricas nos tipos de penalidade e sua severidade a partir de processos econômicos e políticos, respectivamente. As lógicas das agências do castigo (2) podem ser bem compreendidas através de Max Weber (1997). Por meio de categorias como a profissionalização, a burocratização e a racionalização do direito, sustenta o porquê de atualmente as práticas punitivas serem interpretadas pelos funcionários do Estado em termos administrativos - de meios a fins. David Garland (2006), ao tempo que constrói o mais importante marco teórico sobre o castigo, se foca no segundo momento do ciclo: as lógicas de ação dos "operativos" do sistema penal, os juízes, guardas das prisões, funcionários que tomam decisões sobre a liberdade, etc. A respeito da execução da penalidade (3), último momento do ciclo punitivo, Goffman (2001) e Foucault $(2002,1997,1995)$ esclarecem o sentido dos cárceres como instituições totais que procuram a disciplina.

Tal como sugere Garland, o castigo é, simultaneamente, causa e efeito da cultura dominante (Garland, 2006). A teoria dos sistemas de Niklas Luhmann $(1994,2005)$ permite, no final do artigo, integrar as teorias jurídicas e as teorias sociais da penalidade sobre a autopoiese do direito e suas relações com a política, a economia, a religião e a cultura ${ }^{5}$.

\section{Durkheim: 0 Castigo como Expressão da Moral e do Grau de Democratização}

Durkheim formulou pelo menos três ideias medulares para discutir a punição formal. A primeira é a de que o repúdio ao crime é uma importante fonte de afirmação dos valores sociais vigentes que contribui à coesão social. As leis penais têm, sobretudo, uma dimensão simbólica de materialização da moral vigente. Dentro da mesma sociedade coexistem os dois tipos de solidariedade: a mecânica, que é característica das relações cara a cara, e a orgânica, que predomina nas sociedades com alto grau de divisão do trabalho social (2013). Estudando as instituições associadas à punição (judiciário, polícia e legislação positiva) seria possível conhecer o tipo de integração social (Durkheim, 2013; Spitzer, 1975).

Todavia, os trabalhos inspirados em Durkheim, que tentaram provar o estado das relações sociais a partir das instituições penais, esbarraram em sérias objeções metodológicas. Durkheim saltou entre diversos níveis da realidade social, das instituições para as interações. Ordem jurídica e ordem social não são assimiláveis entre si, dado que a legislação não é necessariamente um espelho da realidade social. Ao contrário 
disso, muitas vezes o direito procura reformar a sociedade. Assim, uma série de trabalhos contemporâneos reivindica a ideia de Durkheim para compreendermos as instituições como conjuntos de valores e interesses, tendo maiores precauções metodológicas (Schwartz e Miller, 1964; Baxi, 1974; Spitzer, 1975). Ainda segundo Durkheim, o Estado interpreta a "consciência coletiva", ideia que também é problemática. Se assume nesta pesquisa que as leis penais são um dos mecanismos de construção social da negatividade, junto com a moral e as convenções; as leis penais:

Expressam emoções e reafirmam formas específicas de autoridade [...]. Porém, essas regras, condutas, emoções, crenças e formas de autoridade não necessariamente coincidem com [a vontade] da "sociedade", nem estão sancionadas de tal modo que fomentem a harmonia social (Garland, 2006:103).

Tampouco é verdade que a punição promova a solidariedade social. O castigo "deveria considerar-se como uma tentativa ritualizada de reconstituir e reforçar as relações de autoridade existentes" (Garland, 2006:103).

Outras duas ideias de Durkheim (1899-1900) sobre a punição formal estão expressas nas suas duas "leis" da evolução penal, uma qualitativa e outra quantitativa. $\mathrm{O}$ autor afirmou que a pena de privação da liberdade se torna a punição principal na medida em que as sociedades avançam no grau de individualização das relações. Essa tese, qualitativa, tem tido um desenvolvimento muito maior nas pesquisas de sociologia do direito, a começar por Michel Foucault (1995, 1997, 2002), do que a tese quantitativa, que associa a severidade das punições ao tipo de valores tutelados. As penas tendem a baixar quando se privilegiam bens individuais (propriedade, vida e liberdade, principalmente), em vez de bens coletivos (religião, poder político, sexualidade e trabalho). Justamente por isso as sanções se agravam onde o poder assume feições absolutistas, pois a razão de Estado prima sobre o direito individual. Assim, "a benevolência dos castigos se relaciona com a democracia" (Garland, 2006:58). Essa última ideia de Durkheim foi levada em conta no desenho da pesquisa. A partir da relação entre democracia e severidade das punições, Durkheim inspirou a análise das características da lei penal sob diversos regimes políticos na Colômbia, centralistas/conservadores e federalistas / 
liberais. Observou-se o impacto dos movimentos de concentração e desconcentração do poder na severidade das punições segundo os valores ou instituições sociais tutelados.

Finalmente, a concepção de Durkheim sobre o direito penal como regulador das instituições sociais proporcionou ferramentas metodológicas concretas que orientaram a pesquisa empírica. A grande quantidade de tipos penais foi classificada, segundo Durkheim (2013), em delitos públicos e privados, e subdividida em categorias.

\section{A Tradição Marxista: Direito Penal como Ideologia e Instrumento de Classe}

Nas teorias marxiana e marxista, os reformadores das leis penais representam os interesses da classe que promove a criminalização. $\mathrm{O}$ direito penal é, além de produto ideológico burguês, um instrumento funcional para o desenvolvimento do capitalismo, utilizado na contenção da classe operária. Segundo Pasukanis (1976), o direito penal encarna a forma jurídica abstrata, ideologia da burguesia; delitos e penas são "mercadoria com caráter jurídico", intercambiável na forma de um contrato de retrovenda. Para além disso, as punições têm o sentido de ser uma ferramenta direta da luta de classes, utilizada contra os marginados do sistema econômico. O processo penal é "terrorismo de Estado" (Pasukanis, 1976:148-149). Para Stucka, o direito penal tutela o sistema de relações sociais da classe dominante, protegendo-o das violações ("delitos") com medidas de "defesa social" (Stucka, 1974:217).

Os autores marxistas permitem compreender "os determinantes econômicos e políticos da política penal, o papel das instituições penais nas estratégias de dominação de classe, e as maneiras em que a penalidade serve para expressar tanto simbólica quanto materialmente o poder do Estado" (Garland, 2006:105). Mas, apesar das importantes contribuições à teoria social do castigo institucionalizado, a compreensão do castigo a partir do conceito de ideologia desenvolvido por Marx e pelos marxistas ortodoxos é limitada, uma vez que desconsidera os significados culturais da punição. Para o Garland:

[O] direito penal é, simultaneamente, fonte de proteção e de "terror" para as classes trabalhadoras, e indubitavelmente, alguns de seus aspectos involucram uma função social, como proibir a violência ou castigar os criminais. Se bem a penalidade serve aos fins de certa classe, o faz de tal jeito, que 
garante o apoio das classes subordinadas, protegendo os interesses que se consideram universais sobre os particulares. A chave para entender o direito penal em termos de classe é reconhecer as maneiras em que se entrecruzam os interesses particulares com os gerais (2006:144).

Desta forma, a lei penal não é criada pela classe dominante unilateralmente, nem pelas classes baixas. "É um compromisso que adota uma posição intermédia. Quando as elites dominantes convertem suas categorias favoritas em leis e políticas institucionais, nunca ignoram exceto em circunstâncias excepcionais - a cultura moral das massas" (Garland, 2006:73).

A mais do anterior, estão as múltiplas acepções de "ideologia" que tem sido usadas na literatura marxiana e marxista (Stone, 1985), e o status cognitivo que se pode dar a ela; certamente não será o de espelho das relações materiais. Essa metáfora assume que há um mundo objetivo que a ideologia reflete, como se houvesse um mundo real e um mundo livre de ideologia (Hunt, 1985). A criminologia crítica, construída por Alessandro Baratta, advertiu que a ação dos grupos de interesse não pode ser transferida imediatamente à ação do Estado, como assumiu erradamente a sociologia do conflito "sem levar em consideração o caráter muito mais complexo da mediação política dos conflitos na sociedade industrial avançada" (Baratta, 2004:139).

Mas as relações entre direito penal e ideologia se compreendem muito bem no sentido de ideologia proposto por Karl Mannheim, segundo quem "o conjunto de leis, ordem racionalizada, é o produto da conciliação de forças irracionais em conflito" (1976:144). Os atores do governo buscam a realização de ideologias, no sentido de programas de ação social e política, e são essas forças em luta que definem o direito penal e o tratamento do sujeito delinquente. Essa concepção do direito esclareceu o desenvolvimento dessa pesquisa. Diante disso, fez-se necessário explorar:

1. As mudanças do governo (executivo e legislativo), através da reconstrução e do cruzamento das datas em que ocorreram mudanças de governos conservadores para liberais ou vice-versa, e a forma de organização do poder que promoveram esses governos, com os liberais promovendo reformas constitucionais dirigidas à adoção do federalismo, e conservadores centralizando o poder estatal. 
2. As relações dos reformadores (redatores de projetos de códigos penais) com a elite que exercia nesse momento o poder político, através das biografias dos autores dos projetos de código penal, e da exploração de suas relações com o governo.

O caminho de pesquisa marxista permitiu explicar a direção ideológica adotada nas mudanças jurídicas em dois países: Brasil e Colômbia. A literatura marxista sobre criminalização primária favoreceu a compreensão das reformas penais como consequência das tensões entre as elites nacionais por motivos ideológicos. Na Colômbia, o utilitarismo e o tradicionalismo foram guias para a ação política das elites dos partidos liberal e conservador, respectivamente (Peñas-Felizzola, 2006a; 2006b).

\section{Merton e Elias: A Lei Penal como Mecanismo de Controle de Violências Reais}

Na formulação de Merton, a punição formal é lida como meio institucional que procura evitar a anomia, a desmoralização e a desinstitucionalização de indivíduos e grupos sociais. O catálogo de crimes violentos e de comportamentos proibidos se incrementa quando se divorciam a ênfase nos modos culturalmente admitidos de atingir o sucesso, e a ênfase na coordenação institucional (Merton, 1938). Essa interpretação cultural da relação entre a punição formal e as violências reais aproxima Merton das teorias do processo civilizatório de Norbert Elias (1994, 1997). O catálogo de condutas consideradas crimes em cada sociedade, e entre estas, as mais severamente punidas, muda em decorrência do que Elias caracterizou como processo civilizador - entendido como a eliminação das violências nas interações humanas, decorrente da pacificação atingida pela centralização do poder militar por parte dos monarcas, e que abrange o Estado, o direito e a educação, e se expande às massas sociais (Elias, 1994). Nesse sentido a legislação formal seria apenas uma das manifestações formais do estado do processo civilizador (1997). As mudanças históricas nas formas de sensibilidade, associadas a processos psíquicos e políticos de construção dos Estados modernos.

No Brasil e na Colômbia os reformadores penais expressaram seu propósito de "civilizar" o povo através da legislação penal, fazendo uma reforma moral da cidadania para prevenir as graves violências políticas e ordinárias (Peñas-Felizzola, 2010). Aqui se destaca a relação entre o catálogo de delitos castigados com pena de morte e as violências reais que predominavam na sociedade colombiana do período. 


\section{Foucault: 0 Nascimento da Sociedade Disciplinar}

Foucault destaca a relação entre as formas punitivas e as formas de exercício do poder político. Até finais do século XVIII, nos Estados absolutistas, as finalidades do castigo eram o suplício do corpo (matar com "mil mortes"), e infundir o máximo terror possível, tanto no ajustiçado quanto no público. O castigo tinha uma natureza religiosa, orientada a evidenciar a maldade do delinquente e a obter a confissão do supliciado. Já em meados do século XIX, os processos de constitucionalização do poder, mudanças econômicas que propiciaram novas formas de criminalidade, e o nascimento do sujeito moderno, estiveram associados a importantes transformações na penalidade. Apareceram novas formas de matar que causavam menos sofrimento e se aplicavam de forma "igual para todos" (máquinas de enforcamento e de decapitação). Procuravam também reformar os delinquentes através do encerramento, do trabalho, da castidade, do silêncio, de hábitos de higiene e de disciplina, e da instrução religiosa e laica. Nas palavras de Garland, "Se descobre (...) que a penalidade tem uma relação interna e íntima com o poder, e não é simplesmente seu instrumento ou aliado ocasional" (2006:185). Nessa qualidade radica sua crítica principal à obra do Foucault, segundo a qual ela "somente proporciona uma base parcial para estudar o castigo ou qualquer outra instituição social. [...] Nem o castigo, nem a história penal podem ser compreendidas unicamente através das categorias de poder ou de racionalidade". Por tanto, a obra do Foucault "não pode se considerar um marco explicativo independente para analisar o castigo e as mudanças no sistema penal" (Garland, 2006:188).

Se bem Foucault é uma referência ineludível nos estudos sobre as lógicas de funcionamento das instituições penitenciárias, não era seu interesse decifrar às dinâmicas de produção das leis penais - objeto desta pesquisa. Porém, os importantes trabalhos de Foucault, Vigiar e punir e $A$ verdade e as formas jurídicas, descrevem o contexto em que denuncia a justiça penal tradicional como "bárbara", e propõem inumeráveis projetos de reforma penal que aboliam as velhas compilações jusnaturalistas e procuravam a adoção de códigos penais "modernos". 


\section{Weber: Burocratização, Profissionalização e Racionalização do Direito Penal}

Em relação ao fenômeno da criminalização primária, parte das teorias sociais e jurídicas enfatiza o papel da autoridade política na seleção das condutas consideradas "crimes". Em decorrência disso, propõem uma metodologia centrada nos agentes estatais para se aproximar ao problema da criação da lei penal. Dentro dessa perspectiva destaca-se Max Weber (1997). A burocratização, a racionalização e a profissionalização como categorias explicativas da história do Ocidente permeiam a evolução do castigo. Todas elas têm a ver com processos de expansão e consolidação do Estado moderno. "A partir do século XVIII, os processos do castigo têm sido cada vez mais monopolizados e administrados por instâncias governamentais centralizadas" (Garland, 2006:213-214, 220). Esse fato propiciou a uniformização dos procedimentos de castigo. Atualmente, as práticas punitivas não têm mais uma natureza social; elas são cada vez mais técnicas e profissionais.

[O] sistema penal virou o receptor de vários grupos profissionais - diretores, carcereiros, médicos, trabalhadores sociais, funcionários de liberdade condicional e, posteriormente, criminólogos, psiquiatras e psicólogos - cada um com sua própria jurisdição, estrutura profissional, interesses e ideologia.... [Tudo isso] teve várias consequências sociológicas. Atualmente existe uma elaborada divisão do trabalho, segundo a qual os organismos e funcionários especializados se encarregam das diversas tarefas criminológicas. [Essas diversas instâncias têm], cada uma, suas próprias preocupações e objetivos particulares, e contam com diversas fontes de apoio social (Garland, 2006:215).

Garland confronta a Durkheim com Weber. Afirma que "trata-se de duas visões contrastantes do direito penal contemporâneo": Durkheim destaca "o desejo passional e moralizante de castigar", e [Weber] a preocupação administrativa, racional e normalizadora de dirigir" (Garland, 2006:212). Para ele, na tensão entre ambos significados se encontra um dos determinantes medulares do sistema penal contemporâneo.

A sociologia weberiana esclareceu a pesquisa empírica no sentido de explicar a lei penal como um instrumento para perseguir a realização dos objetivos do Estado. Weber desenvolveu categorias concretas, para analisar a produção das leis nos Estados contemporâneos, que favorecem a compreensão da criação do direito como um processo racional formal. Esse processo se dá por meio de codificações as quais constam de uma parte geral, composta de princípios de interpretação e 
de aplicação das leis penais, e de uma parte especial, em que se desenvolve toda a casuística das proibições. Mas o foco deste artigo não é de analisar a produção da legislação penal na Colômbia, empreitada já realizada (Peñas-Felizzola, 2018a).

\section{METODOLOGIA}

As mudanças nas penas foram observadas através de empiria qualitativa e quantitativa (estatística descritiva), e com enfoque histórico no período que vai de 1830 a 1940 .

O Quadro 1 integra diferentes variáveis apontadas na literatura sobre punição, e considera diversas teorias explicativas das reformas que sancionaram um novo código penal.

Quadro 1

Teorias sobre reforma penal e forma de validação

\begin{tabular}{|c|c|}
\hline $\begin{array}{l}\text { Teoria sobre os fundamentos das grandes } \\
\text { reformas da legislação penal (novos } \\
\text { códigos penais) }\end{array}$ & Forma de validação \\
\hline $\begin{array}{l}\text { Durkheim: } \\
\text { O direito penal reflete o tipo de solidarieda- } \\
\text { de, mecânica ou orgânica, que predomina } \\
\text { numa sociedade } \\
\text { A severidade das punições varia segundo a } \\
\text { forma de distribuição do poder estatal }\end{array}$ & $\begin{array}{l}\text { - Análise quantitativa da severidade das } \\
\text { punições para delitos coletivos e individuais } \\
\text { - Sincronicidade entre as reformas constitu- } \\
\text { cionais que centralizaram ou descentraliza- } \\
\text { ram o poder, e as reformas penais }\end{array}$ \\
\hline $\begin{array}{l}\text { Marxistas: } \\
\text { O direito é um produto da ideologia da } \\
\text { classe no controle do Estado }\end{array}$ & $\begin{array}{l}\text { - Origem dos projetos de códigos (Executivo } \\
\text { ou Legislativo). Trâmite no Legislativo } \\
\text { - Orientação ideológica dos governos que } \\
\text { sancionaram os Códigos }\end{array}$ \\
\hline $\begin{array}{l}\text { Mannheim: } \\
\text { O direito recolhe a ideologia do governo e } \\
\text { as das forças em pugna }\end{array}$ & $\begin{array}{l}\text { - Relação pessoal entre os redatores dos } \\
\text { projetos de código penal e os Presidentes } \\
\text { da República }\end{array}$ \\
\hline $\begin{array}{l}\text { Merton e Elias: } \\
\text { A lei penal é um mecanismo institucionali- } \\
\text { zado de controle de violências reais }\end{array}$ & $\begin{array}{l}\text { - Análise dos delitos castigados com penas } \\
\text { de morte }\end{array}$ \\
\hline $\begin{array}{l}\text { Foucault: } \\
\text { As penas corporais cruéis são eliminadas e } \\
\text { surgem outras penas para castigar "a alma" } \\
\text { do condenado }\end{array}$ & - Mudanças nos tipos de punições previstas \\
\hline
\end{tabular}


Como variáveis dependentes identificaram-se duas expressões da intensidade do poder punitivo: a) as penas mínimas e máximas para diversas categorias de delitos, e b) a severidade das punições, expressa na adoção da pena de morte em distintos períodos políticos e de outros tipos de penalidade.

\section{Fontes da Pesquisa}

As fontes da pesquisa são as codificações penais colombianas, de alcance nacional ${ }^{6}$, vigentes num período de larga duração, a partir da fundação do Estado-nação:

1. O Código Penal de 27 de junho de 1837, que foi o primeiro código penal que regeu na república,

2. O Código Penal de los Estados Unidos de Colombia, Lei 112 de 26 de junho de 1873, que criou o regime "Liberal radical",

3. O Código Penal de la República de Colombia, Lei 19 de 18 de outubro de 1890, obra do regime conservador de "La Regeneración", e

4. O Código de 1936, sancionado na volta do liberalismo ao governo.

\section{Análise Quantitativa dos Códigos Penais: Construção de um Banco de Dados}

A análise quantitativa dos códigos penais se fez em três passos: a elaboração de um inventário de tipos penais em cada codificação penal ${ }^{7}$, o enquadramento dos tipos penais dentro de categorias sociológicas e do direito penal ("bens jurídicos tutelados"), e a comparação das médias das penas previstas para um mesmo grupo de delitos ao longo do tempo.

Para esses propósitos, foi criado um banco de dados com todos os tipos penais previstos em cada um dos códigos analisados. Quatro critérios foram levados em conta para determinar a quantidade de tipos penais: a definição do sujeito ativo da conduta, a definição do sujeito passivo (vítima), as modalidades da conduta (p. ex., com armas/sem armas, $\mathrm{com} / \mathrm{sem}$ violência sobre as pessoas, com/sem violência contra as coisas etc.), e o tipo de pena prevista (se levaram em conta somente as penas privativas da liberdade e a pena de morte) ${ }^{8}$, excluindo penas pecuniárias e restritoras de outros direitos civis e políticos em vez da liberdade pessoal, assim como se especificam as durações mínima e 
máxima da pena, para cada tipo penal. Posteriormente os tipos penais foram agrupados segundo o bem jurídico tutelado. $\mathrm{O}$ banco de dados permite comparar as variações ao longo do tempo na quantidade de tipos penais em cada codificação; no tipo e na intensidade das penas; nos conceitos de crime; e na hierarquia dos bens jurídicos tutelados isto é, valores sociais em auge e em decadência, enquanto se atribui maior ou menor severidade a diferentes condutas.

\section{Tipos de Regras ("Bens Juridicamente Tutelados")}

Os bens jurídicos tutelados são de tipo individual ou coletivo, segundo sua orientação a proteger interesses de pessoas ou de instituições coletivas. Os bens individuais são a vida, a integridade pessoal, a liberdade e a autonomia (tanto física quanto moral, no sentido de fazer a própria vontade), a saúde, o bom nome e a confiança das relações entre indivíduos.

Os bens coletivos correspondem às instituições sociais coletivas que concebem a sociedade como um todo orgânico e tutelam o Estado e suas autoridades; a nacionalidade; a família e as relações sexuais consideradas legítimas; a religião; o trabalho; e as tradições (a moral). Outras instituições coletivas surgiram mais recentemente nos códigos penais, tais como a economia nacional (1936) e o meio ambiente (1980) não entram no recorte temporal da pesquisa.

A classificação de Durkheim sintetiza os bens jurídicos tutelados pelas codificações penais modernas. As regras penais são divididas entre aquelas que têm objetos gerais e as que versam sobre objetos particulares. As regras com objetos gerais seriam as destinadas a defender diversos tipos de sentimentos derivados da solidariedade mecânica ou por semelhanças. Tutelam as instituições religiosas, estatais, familiares, trabalhistas, da nacionalidade, e as que preservam tradições da sociedade. As regras com objetos particulares tutelam atributos do indivíduo derivados da solidariedade orgânica, tais como a vida, o patrimônio econômico, a liberdade física e moral, a honra e a saúde pública.

No percurso da pesquisa se encontraram importantes especificidades nos tipos de regras. A seguir, nos quadros 2 e 3, apresenta-se a classificação de condutas penais elaborada nesta pesquisa. A agrupação dos tipos penais responde a um critério sociológico (instituições sociais), 
e não a critérios ontológicos. Uma importante quantidade de condutas tipificadas como delitos não responde a critérios de lesividade (não tem vítima ou não lesionam um bem juridicamente tutelado): relações sexuais consentidas entre pessoas do mesmo sexo, vagância, mendicância, prostituição, aborto e condutas definidas como lesivas à moral pública etc.

Quadro 2

Classificação das condutas penalizadas: delitos coletivos

\section{Delitos Coletivos}

- Condutas contra funcionários públicos: delitos de sangue (homicídios e ferimentos), ameaças, calúnias, injúrias e difamações; condutas contra os poderes públicos (tentativas de mudar pelas vias de fato a estrutura dos poderes públicos ou os textos constitucionais e legais que estabelecem essa estrutura; rebelião, sedição, assuada, motim, fuga de presos; usurpações das funções do Congresso, Executivo e Judiciário.

1. Delitos contra o - Condutas contra as eleições: violências e fraudes eleitorais. Estado

- Faltas dos funcionários públicos: prevaricações e suborno; formas diversas de corrupção; desacatos, abusos de poder, negligência, expropriações e exações indevidas a particulares.

- Fraudes, falsidades e condutas contra o monopólio fiscal: fraudes, falsidades documentárias, apropriações de fundos públicos (por funcionários e por particulares); falsidade de moeda, documentos e selos públicos e outros delitos contra o monopólio fiscal.

2. Condutas contra os deveres derivados da nacionalidade
- Provocação de guerra exterior, traição à pátria (se configurava quando um nacional apoiava tropas inimigas), espionagem e desrespeito a símbolos pátrios.

3. Condutas contra os deveres de humanidade e cívicos

- Omissão de assistência e socorro a particulares e omissão de prestar ajuda à autoridade.

- Assistir a cultos não permitidos; desrespeito contra cultos

4. Condutas contra a religião e as tradições (sepultura) permitidos e contra autoridades religiosas; propagar doutrinas contrárias aos cultos permitidos; perseguições por motivos religiosos; profanação de cadáveres e furto de objetos das sepulturas. 
Quadro 2

Classificação das condutas penalizadas: delitos coletivos (cont.)

\section{Delitos Coletivos}

- Relações sexuais mediante violência física, castração, com vícios do consentimento ou com abuso da posição de superioridade, rapto de mulheres para contrair casamento.

- Relações sexuais ou proxenetismo com crianças.

5. Violência sexual

- Uniões proibidas: atos sexuais com pessoas do mesmo sexo, e condutas contra com alienados mentais, com contaminação de doenças venéreas; as relações sexuais "amancebamentos", casamentos viciados por impedimentos; consideradas legítimas bigamia e adultério.

- Condutas contra o cuidado e a filiação legítima das crianças: abandono, rapto, troca de filhos, partos fingidos, omissão de registrar os filhos menores e de dar-lhes educação.

- Descumprimento de deveres filiais e desacatos graves contra os pais.

- Executar atos ou publicar impressos ofensivos da moral; per-

6. Condutas contra a moral e o pudor públicos mitir o exercício da prostituição; praticar atos sexuais mediante recompensa; proxenetismo; uso de marcas comerciais ofensivas do decoro público; tráfico internacional de mulheres; escritos e objetos obscenos.

7. Condutas contra o

- Evasões ao dever do trabalho (vagância); embriaguez e prática trabalho e regras sobre profissões de jogos; mendicância; impedimento de um funcionário público a um particular para exercer sua profissão; greve e paralisações dos trabalhadores. 
Quadro 3

Classificação das condutas penalizadas: delitos individuais

\begin{tabular}{|c|c|}
\hline \multicolumn{2}{|r|}{ Delitos Individuais } \\
\hline $\begin{array}{l}\text { 1. Condutas contra a } \\
\text { vida e a integridade } \\
\text { física }\end{array}$ & $\begin{array}{l}\text { - Homicídio e delitos de perigo comum: incêndio, explosão, } \\
\text { inundação, sinistro em meios de transporte coletivo e envenena- } \\
\text { mento de aquedutos. } \\
\text { - Aborto } \\
\text { - Ferimentos } \\
\text { - Rixa e ameaças }\end{array}$ \\
\hline $\begin{array}{l}\text { 2. Condutas contra a } \\
\text { liberdade física }\end{array}$ & $\begin{array}{l}\text { - Diversas modalidades de rapto e sequestro; privações ilegais da } \\
\text { liberdade por funcionário público. }\end{array}$ \\
\hline $\begin{array}{l}\text { 3. Condutas contra a } \\
\text { propriedade privada } \\
\text { a boa-fé nas relações } \\
\text { privadas }\end{array}$ & $\begin{array}{l}\text { - Furtos simples e com violência } \\
\text { - Estelionato, fraudes, violação de direitos autorais, falsidade em } \\
\text { documentos privados, pessoal, de pesos e medidas } \\
\text { - Danos em coisas; danos em animais } \\
\text { - Perturbações da posse } \\
\text { - Quebras fraudulentas } \\
\text { - Falsidades em documentos privados, de selos, pesos e medidas, } \\
\text { e falsidades pessoais }\end{array}$ \\
\hline $\begin{array}{l}\text { 4. Condutas contra a } \\
\text { autonomia moral }\end{array}$ & $\begin{array}{l}\text { - Constrangimentos à autonomia dos indivíduos, como extorsões } \\
\text { e disposição de bens de pessoas que não têm capacidade jurídi- } \\
\text { ca para administrar seu próprio patrimônio. }\end{array}$ \\
\hline $\begin{array}{l}\text { 5. Violações da privacida- } \\
\text { de e condutas contra a } \\
\text { honra das pessoas }\end{array}$ & $\begin{array}{l}\text { - Violação de correspondência } \\
\text { - Injúrias, calúnias e difamações }\end{array}$ \\
\hline $\begin{array}{l}\text { 6. Condutas contra a } \\
\text { saúde pública }\end{array}$ & $\begin{array}{l}\text { - Exercício ilegal da medicina, da farmácia ou da obstetrícia, con- } \\
\text { tágio de doença, contaminação de águas, de medicamentos ou } \\
\text { de alimentos, comércio de entorpecentes, violação de quarente- } \\
\text { na, omissão de denunciar doença. }\end{array}$ \\
\hline 7. Condutas de perigo & $\begin{array}{l}\text { - Condutas vistas como antecipatórias de crimes, mesmo que não } \\
\text { ocasionassem lesão aos direitos de alguém (delitos sem vítima e } \\
\text { sem vulneração de um bem jurídico), especificamente: formação } \\
\text { de quadrilhas, apologia do crime, ou "propor" a alguém come- } \\
\text { ter um delito. }\end{array}$ \\
\hline
\end{tabular}

\section{RESULTADOS DA PESQUISA}

Em seguida, são apresentados os resultados da aplicação das teorias da punição que destacam a conexão entre a severidade das penas, mudanças na ideologia do governo, e movimentos de centralização e/ou descentralização do poder. 


\section{Sincronia entre as Reformas Constitucionais, Mudanças na Ideologia das Elites e as Grandes Reformas Penais}

O Quadro 4 apresenta as datas de adoção de novos códigos penais, de aprovação de novas constituições, de mudanças na forma de distribuição do poder, e de alternâncias na ideologia do governo nacional.

Quadro 4

Reformas constitucionais, mudanças na ideologia do governo e novos códigos penais

\begin{tabular}{|c|c|c|c|}
\hline $\begin{array}{c}\text { Ano novo } \\
\text { Código Penal }\end{array}$ & $\begin{array}{l}\text { Ano de nova } \\
\text { Constituição }\end{array}$ & $\begin{array}{l}\text { Forma de organi- } \\
\text { zação de poderes }\end{array}$ & $\begin{array}{l}\text { Ideologia política do } \\
\text { governo }\end{array}$ \\
\hline \multirow{3}{*}{1837} & 1821 & Centralista & $\begin{array}{l}\text { Republicanismo } \\
\text { anticolonialista (1810-1819) }\end{array}$ \\
\hline & 1830 & Centralista & $\begin{array}{c}\text { Republicanismo } \\
\text { semiliberal (1826-1831) }\end{array}$ \\
\hline & 1832 & Regionalista & $\begin{array}{l}\text { Republicanismo } \\
\text { semiliberal }\end{array}$ \\
\hline \multirow{3}{*}{$\begin{array}{l}1858 \text { (códigos dos } \\
\text { Estados federais) }\end{array}$} & 1843 & Centralista & $\begin{array}{c}\text { Conservadorismo } \\
\text { (1843-1849) }\end{array}$ \\
\hline & 1853 & Federal & \multirow{3}{*}{$\begin{array}{l}\text { Liberalismo forte } \\
\quad(1850 \text {-1886) }\end{array}$} \\
\hline & 1858 & Federal & \\
\hline 1873 & 1863 & Federal & \\
\hline $\begin{array}{l}1887 \\
1890\end{array}$ & 1886 & Centralista & $\begin{array}{l}\text { Nacionalismo e conserva- } \\
\text { dorismo (1886 -909) }\end{array}$ \\
\hline \multirow[t]{2}{*}{1936} & 1910 & Centralista & $\begin{array}{c}\text { Republicana moderada } \\
\text { liberal - conservadora } \\
\text { (1910-1949) }\end{array}$ \\
\hline & 1936 & Centralista & $\begin{array}{l}\text { Democracia social } \\
\quad(1936-948)\end{array}$ \\
\hline 1980 & 1949 & Centralista & $\begin{array}{l}\text { Anticonstitucionalismo e } \\
\text { "estado-de-sitismo"9 } \\
(1949 \text {-1990) }\end{array}$ \\
\hline 2000 & 1991 & Centralista & $\begin{array}{c}\text { Democrática } \\
\text { Pluralista } \\
\text { Multiculturalista (1991-) }\end{array}$ \\
\hline
\end{tabular}


A relação estreita entre as reformas constitucionais e a adoção de novos códigos penais fica clara quando se observa no Quadro 4 que:

- As datas de sanção dos códigos penais coincidem com a expedição de novas constituições políticas ${ }^{10}$.

- As mudanças de um sistema centralista para um federal (ou vice-versa) ocorreram simultaneamente às mudanças ideológicas no governo: o liberalismo se orientou a implantar um sistema federal e o conservadorismo teve sempre reivindicações centralistas. Portanto, não é possível considerar separadamente a influência de cada fator (ideologia e forma de organização do poder) nas reformas penais.

- Nem todas as reformas constitucionais provocaram a sanção de novos códigos penais. Isso só aconteceu quando a ideologia do regime mudou. Em ordem, ocorreram mudanças na orientação utilitarista para a liberal, conservadora, nacionalista e democrática. $\mathrm{O}$ direito penal colombiano mostra-se altamente influenciado por vieses ideológicos.

- Embora só uma Constituição tenha vigorado na Colômbia ao longo de um século (1886-1991), duas reformas na Constituição de 1886 demandaram a sanção de novos estatutos penais. A reforma liberal de 1936 está estreitamente relacionada à expedição do Código Penal mesmo desse ano, assim como a sanção do código penal de 1980 se deu num contexto de tentativas falidas de reforma constitucional ${ }^{11}$.

\section{Severidade das Penas}

Com a análise das punições previstas, confirmou-se a tese de Foucault sobre a tendência à eliminação das penas corporais cruéis e sua substituição por penas privativas da liberdade pessoal e da autonomia moral. No primeiro Código Penal se previa uma grande variedade de punições, que foram decrescendo ao longo do século ${ }^{12}$. A pena de morte, prevista em 1837 para 22 delitos diferentes, foi abolida no começo do século XX (Quadro 5). 
Quadro 5

Delitos com pena de morte na Colômbia

\begin{tabular}{|c|c|}
\hline Norma & Colômbia \\
\hline $\begin{array}{l}\text { Código Penal } \\
\text { de } 1837\end{array}$ & $\begin{array}{l}\text { 1. Tentativa de traição com armas } \\
\text { 2. Rebelião } \\
\text { 3. Sedição } \\
\text { 4. Tomar armas contra a república } \\
\text { 5. Induzir guerra exterior } \\
\text { 6. Incitação à guerra } \\
\text { 7. Comunicação com inimigos } \\
\text { 8. Facilitar a entrada de tropas inimigas } \\
\text { 9. Passar-se ao inimigo em tempo de guerra } \\
\text { 10. Prestar ao inimigo serviço prejudicial à nação } \\
\text { 11. Espionagem } \\
\text { 12. Acolher espiãs } \\
\text { 13. Homicídio premeditado } \\
\text { 14. Assassinato } \\
\text { 15. Latrocínio } \\
\text { 16. Parricídio } \\
\text { 17. Envenenamento humano } \\
\text { 18. Incêndio em propriedade particular } \\
\text { 19. Pirataria } \\
\text { 20. Incêndio em lugar habitado } \\
\text { 21. Inundação, explosão, naufrágio } \\
\text { 22. Envenenamento de aquedutos }\end{array}$ \\
\hline $\begin{array}{l}\text { Código Penal } \\
\text { de } 1890\end{array}$ & $\begin{array}{l}\text { 1. Matar ou causar ferimentos em autoridade encarregada de conter rebelião } \\
\text { 2. Tomar armas contra a nação (por parte de um funcionário público) } \\
\text { 3. Passar-se um funcionário público ao inimigo em tempos de guerra } \\
\text { 4. Espionagem por funcionário público } \\
\text { 5. Comunicar plano a inimigos (por parte de um funcionário público) } \\
\text { 6. Facilitar a entrada de tropas inimigas (por parte de um funcionário público) } \\
\text { 7. Assalto em quadrilhas } \\
\text { 8. Homicídio agravado ( } 8 \text { causais) } \\
\text { 9. Parricídio } \\
\text { 10. Envenenamento de água em casa particular } \\
\text { 11. Envenenamento para matar } \\
\text { 12. Incêndio para matar } \\
\text { 13. Casos graves de pirataria } \\
\text { 14. Sequestro seguido de morte } \\
\text { 15. Inundação, explosão } \\
\text { 16. Envenenar aquedutos públicos }\end{array}$ \\
\hline $\begin{array}{l}\text { Acto Legisla- } \\
\text { tivo } 3 \text { de } 1910\end{array}$ & Abolida \\
\hline
\end{tabular}

DADOS, Rio de Janeiro, vol.63(2): e20180151, 2020. 
O poder punitivo foi muito violento durante todo o século XIX e até o começo do XX, quando a pena capital foi abolida (1910). A pena de morte era prevista para exterminar inimigos políticos: metade das razões que embasavam sua aplicação tinham a ver com delitos políticos, contra a existência do Estado e de traição à pátria. Outras causas para as penas de morte eram o homicídio e os delitos de perigo comum. Houve um período no regime liberal no qual ela foi provisoriamente abolida pela Constituição de 1863, que limitou a duração das penas privativas da liberdade a um máximo de dez anos e aboliu a pena de morte. Foi uma aspiração do liberalismo colombiano de humanizar o sistema penal criado sob influência do tradicionalismo, criticado por sua barbárie. A volta do regime conservador restabeleceu a pena de morte e a aplicou sobre 24 formas de conduta. No começo do século XX a pena de morte foi abolida.

A quantidade de tipos penais nos códigos também variou segundo o regime político:

Gráfico 1

Total tipos penais na Colômbia 1837-1936

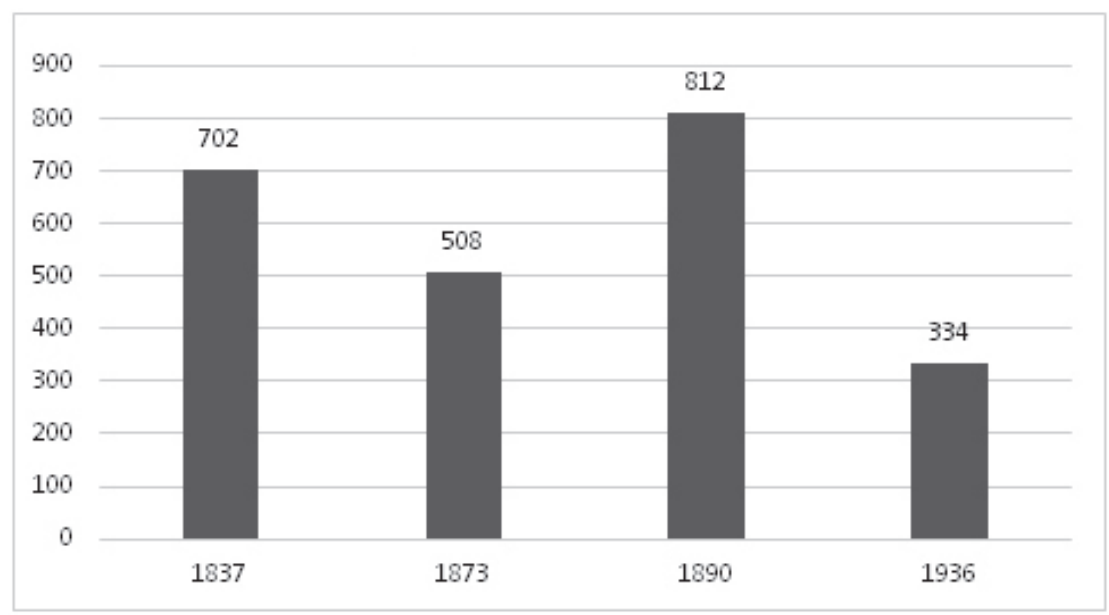

Fonte: elaboração própria com dados dos códigos penais.

Nos governos conservadores os códigos $(1837,1890)$ introduziram mais tipos penais (condutas definidas como delitos) que nos governos liberais $(1873,1936)$.

Concluindo, as mudanças de regime influenciaram muito a severidade das penas. A seguir são apresentados os dados correspondentes à duração média das punições. 


\section{Dados sobre Delitos Coletivos}

A Tabela 1 mostra as penas mínimas e máximas para cada categoria de delitos coletivos, ressaltando em itálico as três categorias de delitos com maiores penas mínimas e máximas.

Tabela 1

Delitos coletivos: penas mínimas e penas máximas nos Códigos Penais da Colômbia (1830-1940)

\begin{tabular}{|c|c|c|c|c|c|c|c|c|c|}
\hline \multirow{2}{*}{\multicolumn{2}{|c|}{ Delitos Coletivos }} & \multicolumn{8}{|c|}{ Código Penal Da Colômbia } \\
\hline & & \multicolumn{2}{|c|}{1837} & \multicolumn{2}{|c|}{1873} & \multicolumn{2}{|c|}{1890} & \multicolumn{2}{|c|}{1936} \\
\hline \multirow{5}{*}{$\begin{array}{l}\text { Delitos con- } \\
\text { tra o Estado }\end{array}$} & \multirow{3}{*}{$\begin{array}{l}\text { Condutas contra } \\
\text { funcionários } \\
\text { públicos e contra os } \\
\text { poderes públicos } \\
\text { Condutas contra as } \\
\text { eleições }\end{array}$} & \multicolumn{2}{|c|}{ Mín/Máx } & \multicolumn{2}{|c|}{ Mín/Máx } & \multicolumn{2}{|c|}{ Mín/Máx } & \multicolumn{2}{|c|}{ Mín/Máx } \\
\hline & & 4,4 & 6,7 & 1,3 & 3 & 2,5 & 4,5 & 0,5 & 2,6 \\
\hline & & 2,3 & 4,8 & NT & NT & NT & NT & 0,3 & 1,6 \\
\hline & $\begin{array}{l}\text { Faltas dos funcioná- } \\
\text { rios públicos }\end{array}$ & 1,7 & 3,5 & 0,9 & 2,4 & 0,8 & 2,6 & 0,5 & 3,4 \\
\hline & $\begin{array}{l}\text { Fraudes, falsidades } \\
\text { e condutas contra o } \\
\text { monopólio fiscal }\end{array}$ & 4,4 & 7,7 & 1,6 & 3,3 & 2,4 & 5 & 1,2 & 5,8 \\
\hline \multicolumn{2}{|c|}{$\begin{array}{l}\text { Condutas contra deveres de } \\
\text { nacionalidade }\end{array}$} & 19,5 & 28,1 & 5,3 & 6 & 9,4 & 13 & 5,1 & 9,6 \\
\hline \multicolumn{2}{|c|}{$\begin{array}{l}\text { Condutas contra deveres humanitá- } \\
\text { rios e cívicos }\end{array}$} & 0,1 & 0,3 & 0,005 & 0,032 & 0,009 & 0,9 & * & * \\
\hline \multicolumn{2}{|c|}{$\begin{array}{l}\text { Condutas contra a religião e tradi- } \\
\text { ções (sepultura) }\end{array}$} & 0,1 & 0,6 & 0,32 & 1 & 0,2 & 1 & 0,2 & 1,1 \\
\hline \multirow{4}{*}{$\begin{array}{l}\text { Violência } \\
\text { sexual e con- } \\
\text { dutas contra } \\
\text { as relações } \\
\text { sexuais } \\
\text { consideradas } \\
\text { legítimas }\end{array}$} & $\begin{array}{l}\text { Violência sexual } \\
\text { e relações sexuais } \\
\text { com vícios de } \\
\text { consentimento } \\
\end{array}$ & 6,2 & 9 & 2 & 3,5 & 4,8 & 7,2 & 1,4 & 5,8 \\
\hline & $\begin{array}{l}\text { Relações sexuais } \\
\text { com menores de } \\
\text { idade, proxenetismo } \\
\text { com menores }\end{array}$ & 4,2 & 7,4 & 2,7 & 4,3 & 3,2 & 6 & 0,8 & 4,5 \\
\hline & Uniões proibidas & 1,7 & 4 & 0,7 & 2,2 & 1,5 & 3,5 & 0,7 & 2,9 \\
\hline & $\begin{array}{l}\text { Condutas contra } \\
\text { o cuidado e } \\
\text { filiação legítima das } \\
\text { crianças }\end{array}$ & 1,6 & 3,3 & 1,2 & 2,3 & 2,4 & 4,3 & 0,8 & 3,6 \\
\hline
\end{tabular}


Tabela 1

Delitos coletivos: penas mínimas e penas máximas nos Códigos Penais da Colômbia (1830-1940) (cont.)

\begin{tabular}{lcccccccc}
\hline \multirow{2}{*}{ Delitos Coletivos } & \multicolumn{7}{c}{ Código Penal Da Colômbia } \\
& 1837 & 1873 & 1890 & 1936 \\
\hline & Mín/Máx & Mín/Máx & Mín/Máx & Mín/Máx \\
$\begin{array}{l}\text { Condutas contra a moral e o pudor } \\
\text { públicos }\end{array}$ & 0,7 & 1,6 & NT & NT & 0,6 & 1,4 & 0,3 & 1,7 \\
\hline $\begin{array}{l}\text { Condutas contra o trabalho e regras } \\
\text { sobre profissões }\end{array}$ & $*$ & $*$ & $*$ & $*$ & $*$ & $*$ & 0,2 & 1,5 \\
\hline
\end{tabular}

* As condutas tipificadas não têm pena corporal prevista. NT = Condutas não tipificadas como delito no Código Penal.

Fonte: elaboração própria com dados dos códigos penais.

Os dados apresentados no Quadro 5 e na Tabela 1, evidenciam que não houve uma tendência unidirecional, mas sim oscilações na severidade das penas segundo a ideologia da administração - tanto para delitos coletivos quanto para os individuais. O Gráfico 1 mostra as médias das penas mínimas e máximas para delitos coletivos, em quatro momentos.

Gráfico 2

Média de penas mínimas e máximas para delitos coletivos

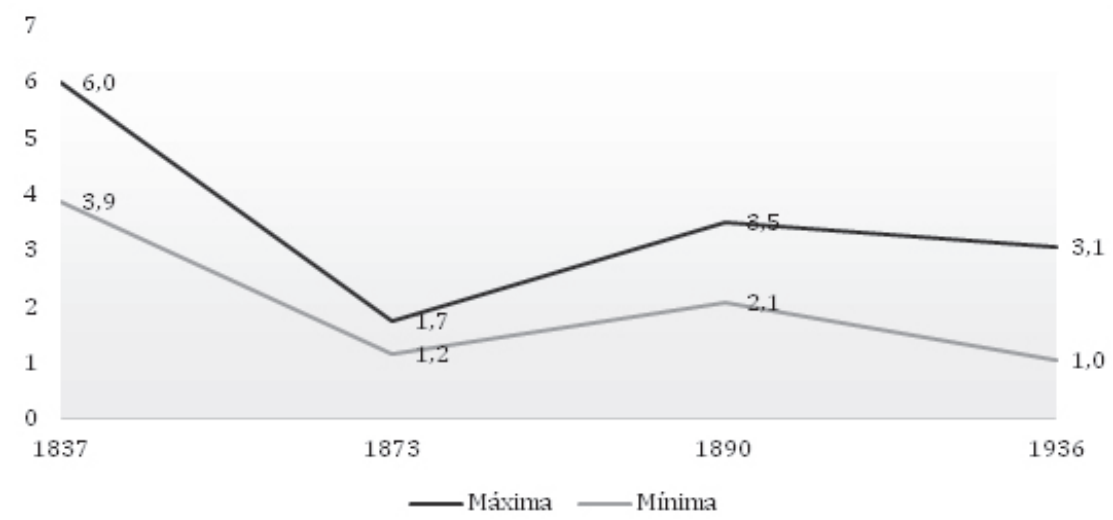

Fonte: elaboração própria com dados dos códigos penais.

Os dois momentos mais punitivos foram a fundação da República (1837) e o início da Hegemonia Conservadora (1890). No final do período, se observa o decréscimo das penas mínimas ao mínimo nível histórico. 


\section{A Hierarquia dos Valores Coletivos Tutelados}

No Gráfico 2 podem ser observadas as médias das penas mínimas e máximas para delitos coletivos, em quatro momentos, desagregadas por instituição social tutelada:

\section{Gráfico 3}

Média das penas previstas para castigar atentados contra instituições sociais coletivas, em quatro cortes de tempo $(1837,1873,1890$ e 1936)

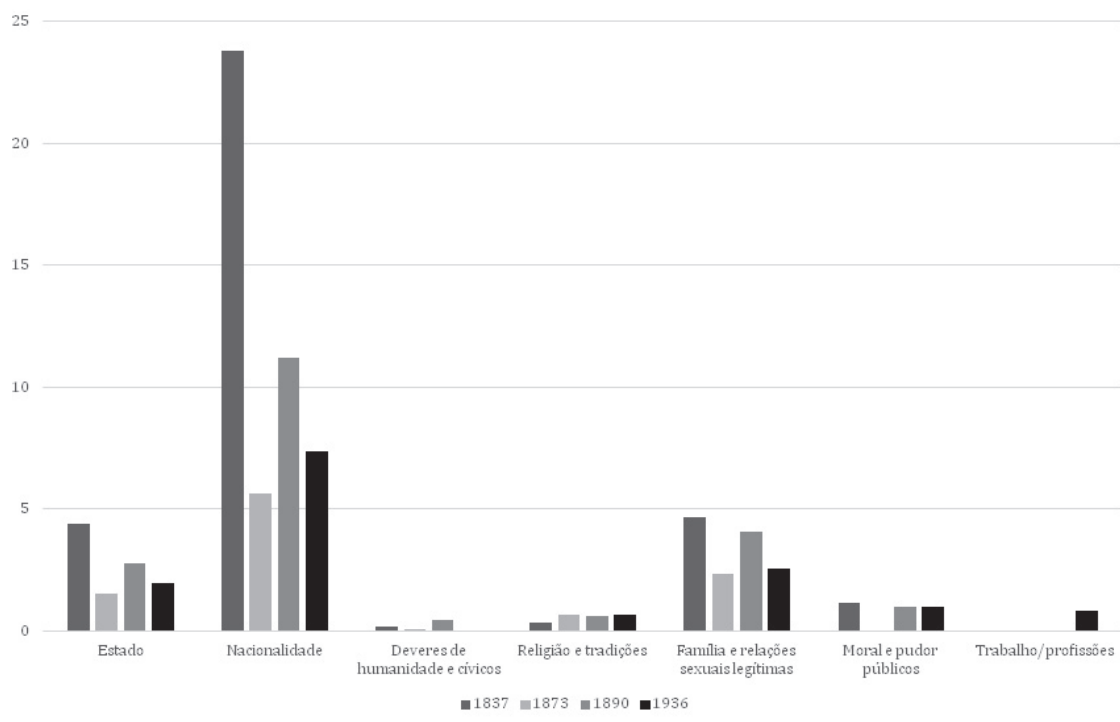

Fonte: elaboração própria com dados dos códigos penais.

- O Gráfico 2 permite visualizar que a intensidade do poder punitivo muda segundo o grau de autoritarismo do regime político, e fase da construção de Estado nacional. O nacionalismo, a defesa da família tradicional, e a prevalência do princípio de segurança do Estado sobre os direitos individuais são justamente os valores mais defendidos pelos regimes autoritários.

- No tocante aos atentados contra a nacionalidade, a chegada do regime liberal radical (1873) esteve associada à diminuição em 75\% do tempo médio de duração das penas previstas em 1837. A instauração do conservadorismo (1890) implicou na duplicação das penas previstas pelos liberais em 1873. E a volta do liberalismo (1936) incidiu na diminuição de 40\% do tempo médio de duração das penas previstas pelos conservadores em 1890. 
- No que toca aos delitos contra a família e as relações sexuais legítimas, o liberalismo forte diminuiu pela metade o tempo médio de duração das penas previstas na fundação da República. Os conservadores duplicaram esse tempo, novamente, em 1890. E os liberais de 1930 reduziram em 40\% as penas mínimas fixadas no regime conservador anterior.

- As penas mínimas para delitos contra o Estado baixaram num 70\% entre a fundação da República (1837) e o regime "Liberal Radical" (1873). Essas penas foram incrementadas em 40\% durante a "Hegemonia Conservadora" (1890), e baixaram novamente em 40\% na volta do liberalismo (1936).

- Na Colômbia, o sistema penal foi utilizado para castigar principalmente três tipos de contravenções. Primeiramente, atentados contra deveres derivados da nacionalidade - apesar de terem ocorrido poucos conflitos armados contra inimigos externos na Colômbia, depois das guerras de Independência contra a Espanha (1810-1819), o Equador (1832) e contra o Peru (1911). Em segundo lugar, atentados contra as relações sexuais legítimas. E em terceiro, delitos contra o Estado, sobretudo fraudes e falsidades em prejuízo do monopólio fiscal. Desta forma, as tendências na hierarquização dos valores no sistema punitivo colombiano permaneceram constantes entre regimes políticos e, portanto, independem tanto da orientação ideológica das reformas políticas como das mudanças na forma de organização do poder (centralismo/federalismo). As ideias de ordem na Colômbia precisam ser explicadas também por fatores culturais, e não só em função do contexto político.

\section{Dados sobre Delitos Individuais}

Na Tabela 2 são apresentados os dados correspondentes a delitos individuais, ressaltando em itálico as três categorias de delitos com maiores penas mínimas e máximas. 
Tabela 2

Delitos individuais: penas mínimas e máximas na Colômbia (1830-1940)

\begin{tabular}{|c|c|c|c|c|c|c|c|c|c|}
\hline \multirow{2}{*}{\multicolumn{2}{|c|}{ DELITOS INDIVIDUAIS }} & \multicolumn{8}{|c|}{ CÓDIGOS PENAIS DA COLÔMBIA } \\
\hline & & \multirow{2}{*}{\multicolumn{2}{|c|}{$\begin{array}{c}1837 \\
\text { Mín/Máx } \\
\end{array}$}} & \multirow{2}{*}{\multicolumn{2}{|c|}{$\begin{array}{c}1873 \\
\text { Mín/Máx }\end{array}$}} & \multirow{2}{*}{\multicolumn{2}{|c|}{$\begin{array}{c}1890 \\
\text { Mín/Máx } \\
\end{array}$}} & \multirow{2}{*}{\multicolumn{2}{|c|}{$\begin{array}{c}1936 \\
\text { Mín/Máx } \\
\end{array}$}} \\
\hline \multirow{5}{*}{$\begin{array}{l}\text { Condutas contra a } \\
\text { vida e a integrida- } \\
\text { de física }\end{array}$} & \multirow{2}{*}{$\begin{array}{l}\text { Homicídio e delitos } \\
\text { de perigo comum }\end{array}$} & & & & & & & & \\
\hline & & 12,1 & 15 & 5,2 & 5,6 & 13,2 & 15,3 & 2,2 & 6,7 \\
\hline & Aborto & 4,7 & 9,1 & 0,8 & 1,7 & 1,7 & 3,7 & 1,2 & 5,8 \\
\hline & Ferimentos & 4,7 & 6 & 2 & 2,7 & 2,4 & 4,2 & 1,4 & 5 \\
\hline & Rixa/s & 0,07 & 0,3 & 1,4 & 3 & 0,05 & 0,2 & 0,5 & 3,1 \\
\hline ontra a & liberdade física & 3,6 & 6,3 & 0,9 & 1,9 & 6 & 7,9 & 0,4 & 2,8 \\
\hline \multirow{5}{*}{$\begin{array}{l}\text { Condutas contra } \\
\text { a propriedade } \\
\text { privada e contra a } \\
\text { boa-fé nas relações } \\
\text { privadas }\end{array}$} & & 4 & 6,9 & 1,2 & 2,2 & 2,3 & 3,6 & 1,8 & 7,2 \\
\hline & $\begin{array}{l}\text { Fraude } \\
\text { privad }\end{array}$ & 0,8 & 2,7 & 0,5 & 1,6 & 0,8 & 2 & 0,4 & 2,7 \\
\hline & $\begin{array}{l}\begin{array}{l}\text { Danos em coisas e/ou } \\
\text { animais }\end{array} \\
\end{array}$ & 0,03 & 0,4 & 1 & 1,6 & 0,1 & 0,7 & 0,09 & 1,8 \\
\hline & Perturbações da posse & 0,03 & 0,9 & 0,03 & 0,1 & 0,03 & 01 & 0,4 & 1,9 \\
\hline & Quebras fraudulentas & 6 & 10,5 & 1,5 & 3 & 1,2 & 3 & 0,4 & 3,4 \\
\hline \multicolumn{2}{|c|}{ Condutas contra a autonomia moral } & 1,2 & 4 & 0,5 & 2,4 & 1,7 & 6,7 & 0,4 & 2,3 \\
\hline \multicolumn{2}{|c|}{$\begin{array}{l}\text { Violações da privacidade e condutas } \\
\text { contra a honra }\end{array}$} & 0,4 & 1,4 & 0,3 & 1 & 1,4 & 3,6 & 0,4 & 2,4 \\
\hline \multicolumn{2}{|c|}{ Condutas contra a saúde pública } & 2,7 & 4,3 & 2 & 2 & 2 & 4,8 & 1,2 & 7 \\
\hline \multicolumn{2}{|c|}{ Condutas de perigo } & 1,9 & 6,2 & 1 & 2,3 & 1,2 & 3,2 & 0,5 & 3,1 \\
\hline
\end{tabular}

Fonte: elaboração própria com dados dos códigos penais.

\section{A Hierarquia dos Valores Individuais Tutelados}

No Gráfico 4 se apresentam os dados das médias das penas mínimas e máximas para delitos individuais, em quatro momentos: 
Gráfico 4

Média de penas mínimas e máximas para delitos individuais

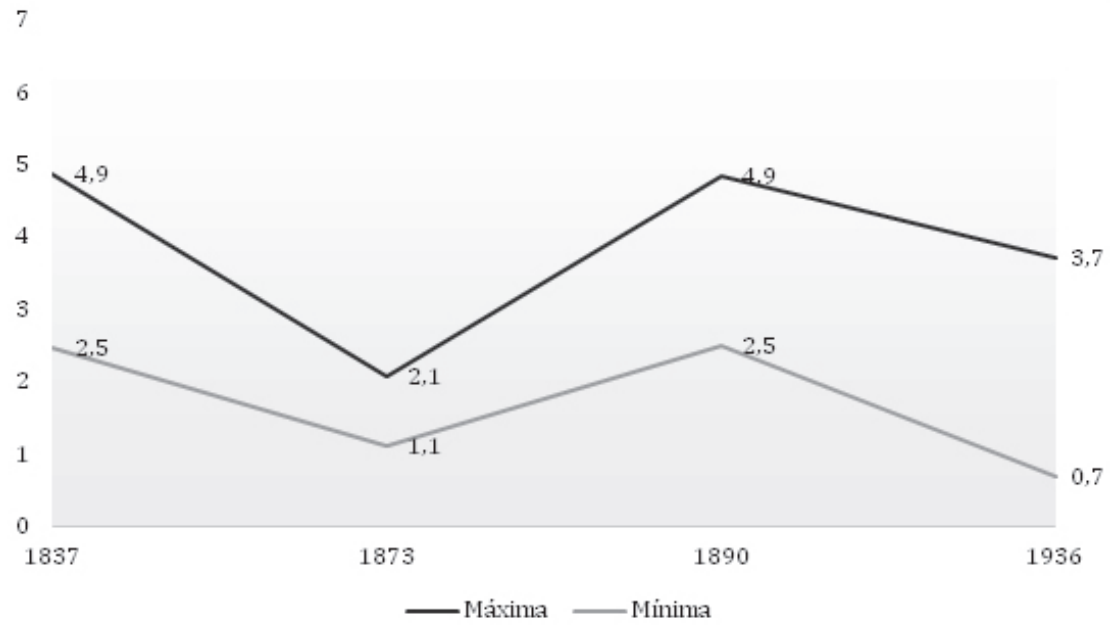

Fonte: elaboração própria com dados dos códigos penais.

No que se refere a delitos individuais, é possível observar os mesmos padrões das punições dos delitos coletivos. Os dois momentos mais punitivos foram a fundação da República (1830) e o início da Hegemonia Conservadora (1890). Para os delitos contra a vida e a integridade física, a liberdade física e a autonomia moral, ocorreram variações significativas nas punições entre regimes políticos. Mas se observa um decréscimo nas penas previstas entre o período que vai de 1830 a 1936 em todas as categorias, exceto para os delitos contra a saúde pública. Essa mudança pode ser explicada pela ideologia de defesa social revigorada pelo positivismo criminológico em voga no começo do século. Nas reformas colombianas de 1890 e 1936 as ênfases foram a regulação econômica, o controle da população marginalizada pelo sistema econômico, e a tutela da saúde pública, inspiradas no positivismo italiano e nas teorias eugenistas europeias. Cada ideologia jurídico-penal definiu seus próprios sujeitos perigosos. As teorias do poder são adaptadas às circunstâncias específicas de cada sociedade. Correntes ideológicas diversas, inclusive contraditórias entre si, confluem para configurar a tradição punitiva nacional (Peñas-Felizzola, 2010). 
Gráfico 5

Média das penas previstas para castigar atentados contra instituições sociais individuais, em quatro cortes de tempo (1837, 1873, 1890 e 1936)

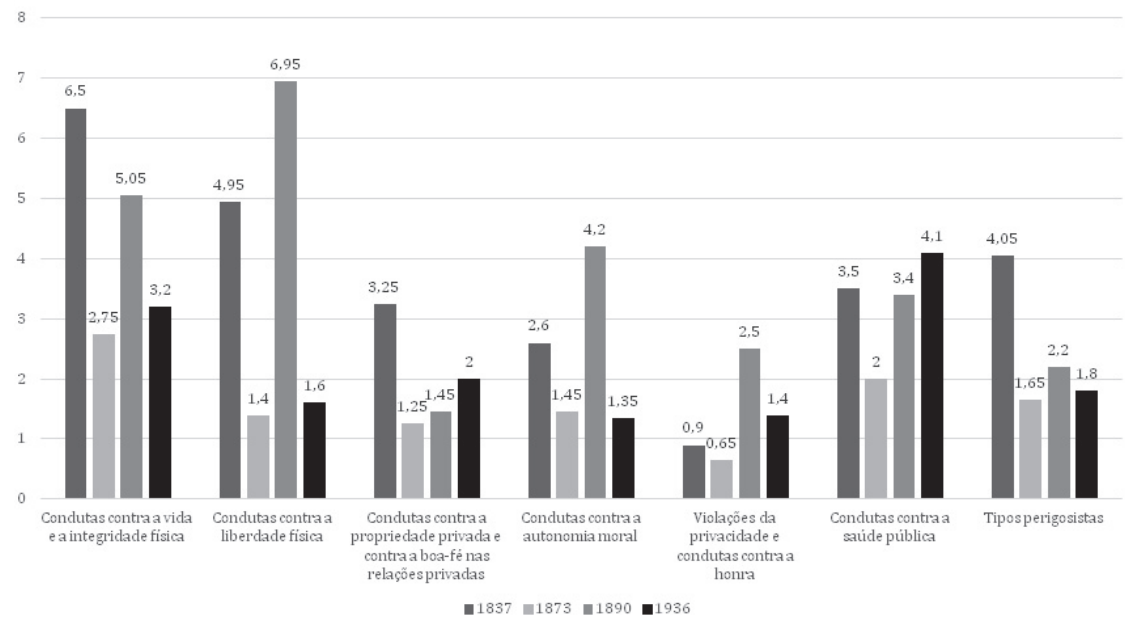

Fonte: elaboração própria com dados dos códigos penais.

\section{CONSIDERAÇÕES FINAIS}

A análise das variações do peso atribuído a diferentes condutas públicas e privadas tipificadas como delitos permite discutir várias questões teóricas e metodológicas formuladas no início do artigo. Uma característica da profusa produção sociológica sobre punição é que, em geral, ela tem tratado o processo de criminalização primária (penas previstas na legislação) como um processo unidirecional - ou como um retrocesso (punitivismo), ou como uma evolução (humanização da pena). Paradoxalmente, os estudos empíricos se veem obrigados a usar como referência as mesmas teorias modernas sobre punição que tentam relativizar empiricamente (Whitman, 2005). Mas os dados mostram que não existe uma tendência unidirecional, e sim oscilações na severidade do poder punitivo.

As teorias marxistas e 0 conceito do direito em Mannheim têm alta capacidade explicativa sobre a política penal

- Mudanças importantes na ideologia do governo geram reformas na orientação da legislação sobre bens/valores individuais ou coletivos, e na severidade das penas (na existência ou não de pena de morte, e na duração das penas). Nos regimes conservadores, orientados pela ideologia tradicionalista 
católica: a) a pena de morte foi reintroduzida, b) o catálogo de condutas puníveis foi incrementado, e c) aumentou a duração das penas de privação da liberdade. Nos regimes liberais foi eliminada a pena de morte, diminuída a quantidade de tipos penais, e reduzidas em até um terço a duração das penas mínimas e máximas.

- Os resultados encontrados se aproximam dos alcançados em outras pesquisas sobre o Brasil contemporâneo, que demostram a expansão do punitivismo legislativo pós-Constituição de 1988, abandeirado pelos partidos de centro e direita (Campos, 2014). Os dados sobre os sistemas penais relacionados à severidade das punições e à proteção/perseguição de grupos sociais permitem evidenciar processos de democratização e "des-democratização" dentro de um mesmo país ao longo do tempo, assim como entre países (Tilly, 2003). Nas reformas penais conservadoras e autoritárias deterioram-se as garantias dos direitos das mulheres, diversidades sexuais, crianças, oposição política, e demais grupos em conflito com a autoridade tradicional.

- Os redatores dos códigos, que foram juristas muito próximos do regime político que os implementaram, tornaram-se agentes da incorporação na legislação positiva da ideologia do regime. São um tipo especial de jurista, mais qualificado tecnicamente que os parlamentares ou assessores presidenciais - que propõem e sancionam leis extravagantes ou decretos penais em situações de conjuntura. Os redatores de códigos penais também têm uma visão de conjunto da política, que não necessariamente tem um impulsionador de leis penais. Se diferenciam três perfis de legisladores penais no Brasil e na Colômbia (Peñas-Felizzola, 2018a). A primeira geração foi a dos ideólogos da fundação do Estado nacional (Código de 1830 no Brasil, e Códigos de 1837, 1873 e 1890 na Colômbia). A segunda geração foi a dos juristas-especialistas (código brasileiro de 1890, e códigos colombianos de 1936 e 1980). Atualmente, o judiciário tem tido um papel protagonista (Projeto de Lei do Senado $n^{\circ}$ 236, de 2012 - novo código penal brasileiro, e código colombiano de 2000).

- Foi encontrado também, confirmando a tese de Mannheim sobre a irracionalidade das forças conflitantes que criam o direito, que a criação de códigos penais e textos medulares de um sistema jurídico só se realiza dentro dos parlamentos de forma marginal. O Executivo tem o controle da agenda punitiva tanto na Colômbia quanto no Brasil (Campos, 2014). Além disso, os níveis de discussão pública dos projetos de códigos penais têm sido muito baixos, levando-se em conta que o castigo penal é a forma extrema da violência legítima do Estado (Peñas-Felizzola, 2018a). 
As mais importantes reformas penais (novos códigos penais) derivaram de mudanças na distribuição do poder (centralização/descentralização), como postulou Durkheim

- A severidade das punições mudou segundo o grau de autoritarismo do regime político. Isso acontece porque o sistema político incrementa as punições relativas a valores coletivos: a existência e seguridade do Estado, a nacionalidade, a religião e as relações sexuais. O liberalismo da codificação penal de 1873 implicou em uma ruptura em relação aos bens tutelados historicamente pelo ordenamento penal colombiano, secularizand o o direito e orientando-o para a proteção da saúde pública, e principalmente da ordem econômica. O Estatuto de 1890 restitui a religião e a regulamentação do casamento ao estado anterior à revolução liberal. A volta do liberalismo na década de 1930 propiciou uma diminuição geral das penas.

- Os bens jurídicos tutelados, que foram sendo incrementados ao longo do século $X X$, não representam instituições e interesses compartilhados pela sociedade como um todo. Alguns valores permanecem estáveis e outros valores fazem parte de programas de reforma moral impostos através da lei por forças políticas no controle do Legislativo. Garland revaloriza os estudos do castigo que, inspirados em Durkheim, olham para o conjunto de valores: "Os códigos penais protegem as necessidades básicas da ordem social - seguridade pública, seguridade pessoal, liberdade individual e proteção da propriedade, entre outros -; isto é, valores profundos e amplamente compartilhados"' (Garland, 2006:77).

\section{As violências reais influenciam a modificação das leis (Elias e Merton)}

Na hierarquia dos valores tutelados historicamente na lei penal na Colômbia, as muitas e sangrentas guerras civis e desmembramentos territoriais vividas pelo país fazem com que os delitos políticos sejam considerados muito graves. $\mathrm{O}$ controle social mediante a legislação se concentrou nos atores políticos dissidentes com pesadas sanções tanto para o delinquente político - derivadas das leis de traição e sedição -, quanto para os cidadãos comuns, que se viram submetidos a fortes responsabilidades em relação aos deveres de nacionalidade. 


\section{Um enfoque sistêmico permite integrar os resultados das pesquisas sobre reformas penais}

- Segundo Niklas Luhmann, o sistema jurídico-penal cumpre a função social de reduzir a complexidade da vida social, definindo o que é legal e o que é ilegal. Assim, facilita a resolução dos conflitos e contribui na estabilização das expectativas normativas sobre a conduta dos indivíduos.

- O direito penal tem lógicas internas de reforma (é autopoiético), mas depende também da emergência de novas teorias jurídicas em âmbito global, como foi demonstrado por Nonet e Selznick (1978). Essas teorias têm se deslocado, de uma concepção utilitarista que justifica o poder mediante o critério de autoridade, passando por uma concepção positivista assentada no legalismo liberal e de afirmação do fenômeno jurídico sobre a "regra de direito", até chegar ao momento atual, em que predomina um direito aberto às mudanças sociais. Os anos de 1837, 1873, 1890 e 1936, datas da aprovação de novos corpos de leis penais na Colômbia, representam não só momentos de renovação das elites políticas nacionais, mas também momentos de recepção de novos modelos de códigos penais na Europa (Zaffaroni, 1994). A criação de novas instituições jurídicas e a circulação de novos modelos de pensamento jurídico-penal são fatores muito relevantes na explicação da oportunidade de duas reformas penais. No Código de 1837, o utilitarismo benthamiano impôs o modelo de legislação francesa napoleônica de primazia da razão do Estado. O segundo modelo de punição formal, que se caracteriza pela influência do positivismo criminológico italiano, se deu por volta da metade do século XIX, com a recepção dos códigos espanhóis de 1848-1850 e 1870, e do "Código Zanardelli", italiano. A terceira onda de reforma ocorreu na terceira década do século XX, quando foram difundidos sobretudo os projetos de Ferri e Rocco, que incorporam elementos periculosos, condenando os indivíduos pelos delitos que poderiam vir a cometer.

- O sistema penal participa na construção da realidade social se comunicando com os diferentes subsistemas. Com a política, desenvolve o marco programático contido nas constituições, consagrando os poderes políticos estabelecidos e apoiando sua aspiração de monopolizar a violência legítima do Estado. Com a economia, impõe novas ideologias mundiais, definindo como ilegais condutas contrárias aos interesses dos agentes econômicos, introduzindo consequências frente ao descumprimento das regras relativas à propriedade e aos contratos, e inspirando terror nos excluídos pelo sistema econômico. Com a religião, protege as autoridades religiosas e os dogmas. Quando o tradicionalismo se enfraqueceu, perdeu sua capacidade de influenciar o subsistema do direito. Com a erosão da moral religiosa, condutas que eram consideradas muito graves na fundação do Estado nacional perderam progressivamente seu caráter 
de transgressão jurídica, caso dos delitos contra a religião e alguns tipos de relações sexuais definidas como ilícitas ("amancebamento"). Com a cultura, apresenta continuidades na proteção de determinados valores que configuram uma espécie de tradição nacional de cultura punitiva. É por isso que, de maneira semelhante aos sistemas constitucionais, os sistemas penais nacionais possuem um núcleo duro que permanece estável no longo prazo, e um componente elástico, produto das variações no regime político, da pressão da opinião pública, e da influência de novas correntes dogmáticas. Uma reforma penal mais liberal do que a sociedade está condenada ao fracasso, como foi ilustrado no caso da Colômbia com a implementação do Código Penal de 1873. As definições formais do direito positivo sobre o que cada sociedade considera anormal, imoral, subversivo da ordem ou antissocial se configuram durante a fase do direito repressivo e tendem a se conservar estáveis por muito tempo. A path dependence (Mahoney, 2000) tem um forte poder explicativo na análise de este tipo de processos para o caso da Colômbia.

- A maior diferenciação das sociedades contemporâneas provoca uma maior complexidade nas relações entre o sistema penal e outros subsistemas. Na análise das reformas penais ocorridas na segunda metade do século XX, é preciso levar em consideração as complexidades do processo legislativo. Mais atores e interesses intervêm nas discussões dos projetos.

Em relação à metodologia das pesquisas sobre criminalização primária, é preciso considerar vários caminhos de pesquisa identificados na literatura especializada. A pertinência de cada teoria precisa ser avaliada a partir da história e dos problemas de cada sociedade. Cada teoria permite determinar um aspecto diferente e importante dos fins perseguidos pelos poderes políticos através de cada novo estatuto punitivo.

(Recebido para publicação em 19 de junho de 2018)

(Reapresentado em 19 de setembro de 2019)

(Aprovado para publicação em 2 de outubro de 2019)

\section{NOTAS}

1. O banco de dados completo inclui esses quatro códigos penais colombianos de 1837, 1873, 1890 e 1936, e os brasileiros de 1830, 1890 e 1940, e se compõe no total de 3.369 tipos penais. O banco de dados faz parte do projeto de pesquisa "Reforma penal em perspectiva histórica e comparada", iniciado com a pesquisa doutoral titulada: "As ideias de ordem social no Brasil e na Colômbia: uma análise da casuística penal", financiada pela Coordenação de Aperfeiçoamento de Pessoal de Nível Superior (Capes) e pela Fundação Carlos Chagas Filho de Amparo à Pesquisa do Estado do Rio de Janeiro (Faperj) (Iuperj/UCAM, 2010). Agradecemos especialmente à Dra. Maria Alice Rezende de Carvalho, orientadora, e à banca examinadora, composta pelos Doutores Luiz 
Werneck Vianna, Gizlene Neder, Cesar Guimarães e Luiz Antônio Machado. O Doutor Nilo Batista acompanhou a qualificação e facilitou a pesquisa comparativa. Cada um deles, com grande inteligência e gentileza, contribuiu significativamente para que esta pesquisa fosse concluída.

2. A ideia da juridificação da moralidade mediante o direito penal, e a imagem de ordem social que a legislação penal constrói, se encontra em Nonet e Selznick (1978). Sobre a dimensão simbólica do direito penal, seu papel de identificar fatos e sujeitos como estranhos à identidade que o grupo social tenta construir, e sua associação contemporânea ao punitivismo, ver Jakobs e Cancio Meliá (2003).

3. Porém, para Mary Douglas, um modelo completo de ordem social envolve as falas dos membros, as estruturas de poder e os padrões de interação dos participantes.

4. Um dos resultados metodológicos derivados da pesquisa é que os códigos penais e as leis extravagantes têm uma natureza sociológica diferente entre si. Enquanto as codificações são modelos completos de ordem social, as leis emendam pequenos desvios da norma com respeito à realidade que se quer construir. Não têm as mesmas pretensões jurídicas nem políticas.

5. Agradecemos muito especialmente aos pareceristas pela sua valiosa sugestão de incorporar a obra de Garland e do Luhmann na parte teórica, e de ampliar a explicação sociológica. Além disso, contribuíram decisivamente na melhor apresentação e esclarecimento dos resultados da pesquisa empírica.

6. Para os efeitos da pesquisa, foram excluídos da análise o Código de 1858, por ser legislação dos Estados e não nacional (em 1858 foram sancionados códigos penais nos "estados federados"; o Estado de Cundinamarca aprovou o seu próprio código, por Lei de 16 de outubro de 1858), e o código de 1887, que vigorou por apenas dois anos. Tratava-se do mesmo Código do Estado de Cundinamarca de 1858, adotado provisoriamente pela Constituição da Regeneración (1886), para invalidar a legislação Liberal Radical. De 1858 até 1887, sob uma organização federal do poder, a criação da legislação penal era atribuição tanto dos Estados federados quanto da União. A legislação penal nacional regeu somente "nos sertões e nos mares", nas palavras de Quijano (1898:V). As leis do parlamento nacional tinham vigência só no mar territorial e nos chamados territórios nacionais, que eram as porções do país que não tinham o status jurídico de Estados por serem áreas povoadas por comunidades indígenas ou isoladas. O código penal liberal, apesar de ter vigorado em poucas áreas geográficas, merece ser objeto de estudo especial por ter rompido com a concepção tradicional da punição na Colômbia.

7. As fontes da pesquisa são os textos originais dos códigos, publicados no momento da sanção, e não os textos atualizados posteriormente, que foram emendados.

8. Nos casos em que a pena era de morte ou de privação perpétua da liberdade, se deu um valor equivalente: 40 anos para a pena de morte e 30 anos para as penas perpétuas de privação da liberdade e de banimento.

9. O conceito de "estado-de-sitismo" refere-se ao abuso da instituição do "estado de sítio" para restringir direitos civis e políticos, e encontra-se em Marquardt (2012).

10. Isso contrasta com a sanção de códigos civis. O único código civil colombiano é datado de 1873 . O procedimento penal também tem sido dependente das variações do sistema 


\section{Aura Helena Peñas Felizzola e Gláucio Ary Dillon Soares}

político: os códigos do processo colombianos datam de 1848, 1872 (código judicial), 1936, 1971, 1991, 2000 e 2004.

11. A Corte Suprema de Justiça declarou inconstitucionais as reformas feitas pelos Atos Legislativos no 2 de 1977 e ํo 1 de 1979.

12. O código de 1837 previa 9 penas corporais e 12 não corporais. As penas corporais eram as de: 1 . Morte; 2 . Trabalhos forçados; 3 . Presídio; 4 . Reclusão em casa de trabalho; 5. Vergonha pública (que consistia na exposição pública como criminoso); 6. Prisão; 7. Expulsão do território da república; 8. Confinamento de um lugar determinado e, 9 . Desterro.

As penas não corporais eram: 1. Infâmia (que consistia na morte civil, com a perda de todos os direitos de cidadão); 2. Suspensão dos direitos políticos e civis; 3 . Privação de direitos civis; 4 . Sujeição à vigilância das autoridades, que consistia em se apresentar periodicamente às autoridades locais para prestar informações sobre domicílio e a ocupação; 5. Inabilitação para exercer cargo público ou profissão particular; 6. Privação de emprego, pensão, profissão ou cargo público; 7. Suspensão dos mesmos; 8 . Arresto; 9. Apercebimento judicial, que consistia numa advertência judicial ao infrator; 10. Fiança de boa conduta; 11. Multa; 12. Perda de efeitos.

Em 1873 já haviam sido abolidas as penas de morte, vergonha e de trabalhos forçados. Entre as não corporais, só foi abolida a infâmia. O Código de 1890 restabelece a pena de morte e mantém as outras penas do código anterior. Em 1940 foram implementadas "medidas de segurança" que permitiam conservar os prisioneiros em manicômios, "casas de custódia" e colônias agrícolas, por tempo indeterminado. 


\section{REFERÊNCIAS}

BARATTA, Alessandro. (2004), Criminología crítica y crítica del derecho penal. Introducción a la sociología jurídico-penal. Buenos Aires: Siglo XXI.

BATISTA, Nilo. (2006), Pena pública e escravismo. Conferência apresentada na Faculdade de Direito da Universidade Federal do Rio de Janeiro, 13 de maio (mimeo).

BAXI, Upendra. (1974), "Durkheim and legal evolution: some problems of disproof". Law E Society Review, v. 8, n. 4, pp. 645-652.

CAMPOS, Marcelo. (2014), “Crime e Congresso Nacional: uma análise da política criminal aprovada de 1989 a 2006". Revista Brasileira de Ciência Politica, n. 15, pp. 315-347. Disponível em: https: / / www.scielo.br/scielo.php?pid=S0103-33522014000300315\&script=sci_ abstract\&tlng=pt. Acessado em 23 de maio de 2020.

MARQUARDT, Bernd (ed.). (2011), El bicentenario del constitucionalismo moderno en Colombia. Bogotá: Ibáñez.

COLOMBIA. (1821), Constitución de la República de Colombia, Cúcuta, Imprenta de Bruno Espinosa. Disponível em: http:/ /www.bdigital.unal.edu.co/21/28/constitucion_de_ la_republica_de_colombia.pdf

. (1832), Constitución del Estado de la Nueva Granada dada por la Convención Constituyente en el año de 1832-22 de la Independencia, Bogotá, Tipografía de Bruno Espinosa: http:/ / www.bdigital.unal.edu.co/219/26/constitucion_del_estado.pdf

. (1873), Congreso de la República, Código penal de los Estados Unidos de Colombia, Lei 112 de 26 de junio de 1873, sancionado por el Congreso de 1873. Bogotá: Imprenta de Medardo Rivas.

. (1887), Congreso de la República, Código Penal, Ley 57 de 1887.

. (1890), Congreso de la República, Código Penal de la República de Colombia, Ley 19 de 18 de octubre de 1890. Bogotá: Imprenta de la Nación.

. (1910), Acto legislativo no 3 reformatorio de la Constitución Nacional, en Diario Oficial, no 14.131 e 14.132 , de 31 de outubro de 1910 .

. (1925), Congreso de la República, “Código Penal de 1837 (junho 27)”. In: Consejo de Estado. Codificación Nacional de todas las leyes de Colombia desde el año de 1821, hecha conforme a la ley 13 de 1912, por la Sala de Negocios Generales del Consejo de Estado, tomo VI, anos de 1836 e 1837. Bogotá: Imprenta Nacional.

- (1936), Congreso de la República, Código Penal, Ley 95 de 24 de abril de 1936, texto definitivo adotado pelo Decreto 2300 de 14 de setembro de 1936, publicado no Diario Oficial n⿳o 23320 de 29 de outubro.

. (1936), Acto Legislativo $\mathrm{n}^{\mathrm{o}} 1$ reformatorio de la Constitución, en Diario Oficial no 23.263, de 22 de agosto.

. (1977), Congreso de la República, Acto Legislativo no 2.

. (1979), Congreso de la República, Acto Legislativo no 1. 


\section{Aura Helena Peñas Felizzola e Gláucio Ary Dillon Soares}

(1980), Presidencia de la República, Código Penal de 1980, Decreto nº 100 de 23 de janeiro. Diario Oficial no 35.461 de 20 de febrero de 1980.

. (1991), Constitución Política de la República de Colombia, en Gaceta Constitucional, no 127 , de 10 de outubro.

. (2000), Congreso de la República, Código Penal, Ley 599 de 24 de julho. Diario Oficial no 44.097, 24 de julho. Disponível em: http: / / www.secretariasenado.gov.co/senado/ basedoc/ley_0599_2000.html. Acessado em 23 de maio de 2020.

. (2016), Gobierno de Colombia, Fuerzas Armadas Revolucionarias Colombianas (Farc). Acuerdo para la terminación del conflicto y la construcción de una paz estable y duradera. La Habana (Cuba), 24 de agosto. Disponível em: https: / /www.jep.gov.co/ Normativa/Paginas/Acuerdo-Final.aspx. Acessado em 23 de maio de 2020.

DOUGLAS, Mary. (1998), Como as instituições pensam. São Paulo: Edusp.

DURKHEIM, Émile. (1899-1900), “Deux lois de l’evolution pénale”. Année Sociologique, v. IV, pp. 65-95. Disponível em: http:/ / classiques.uqac.ca/classiques/Durkheim_emile/annee_sociologique/na_socio_3/evolution_penale.html. Acessado em 23 de maio de 2020.

. (1963), L'education morale. Paris: Presses Universitaires de France.

(2013), La división del trabajo social. Buenos Aires: Lea.

ELIAS, Norbert. (1994), O processo civilizador. Rio de Janeiro: Jorge Zahar Editor. Vol. I e II. . (1997), Os Alemães. A luta pelo poder e a evolução do habitus nos séculos XIX e XX. Rio de Janeiro: Jorge Zahar Editor.

FOUCAULT, Michel. (2002), Em defesa da sociedade. São Paulo: Martins Fontes.

. (1997), Vigiar e punir. Petrópolis: Vozes.

. (1995), Microfísica do poder. Rio de Janeiro: Graal.

GARLAND, David. (2006), Castigo y sociedad moderna: un estudio de teoría social. México: Siglo XXI.

. (2007), Crimen y castigo en la modernidad tardía. Bogotá: Siglo del Hombre, Uniandes, Universidad Javeriana.

GOFFMAN, Erving. (2001), Internados: ensayos sobre la situación social de los enfermos mentales. Buenos Aires: Amorrortu.

HUNT, Alan. (1985) "The ideology of law: advances and problems in recent applications of the concept of ideology to the analysis of law". Law and Society Review, v. 19, n. 1, pp. 11-38.

JAKOBS, Günther; CANCIO-MELIÁ, Manuel. (2003), Derecho penal del enemigo. Madrid: Civitas.

LUHMANN, Niklas. (2005), El derecho de la sociedad. México: Herder. (1994), “El derecho como sistema social”. No hay Derecho, año V, n. 11, pp. 29-33.

MAHONEY, James. (2000), "Path Dependence in Historical Sociology". Theory and Society, v. 29 , n. 4 , pp. 507-548.

DADOS, Rio de Janeiro, vol.63(2): e20180151, 2020. 
MALINOWSKI, Bronislaw. (1964), Crime and custom in savage society. New Jersey: Littlefield.

MANNHEIM, Karl. (1976), Ideologia e utopia. Rio de Janeiro: Zahar.

MARQUARDT, Bernd. (2012), El anti-constitucionalismo en la historia política de Colombia (1949-1990). Bogotá: Temis.

MARX, Karl. (1945), Crítica de la Economía Política. Buenos Aires: Futuro. . (1946), El Capital, tomo III. México: Fondo de Cultura Económica.

MERTON, Robert K. (1938), "Social structure and anomie". American Sociological Review n. 3, pp. 672-682.

NONET, Philippe; SELZNICK, Philip. (1978), Law and society in transition. New York: Octagon Books.

PASUKANIS, Evgene. (1976), Teoría general del derecho y Marxismo. Barcelona: Ed. Labor.

PEÑAS-FELIZZOLA, Aura. (2018a), “El perfil de los redactores de códigos penales en perspectiva comparada (Brasil-Colombia): sobre cómo las ideologías políticas se plasman en el derecho penal". In: E. Escalante (ed.), Política criminal mediática. Populismo penal, criminología crítica de los medios y de la justicia penal. Bogotá: Ibáñez, Universidad Nacional de Colombia, pp. 643-669.

(2018b), "La producción del derecho público y penal en la fundación del Estado nacional en Brasil y Colombia (1808-1849)". In: B. Marquardt; D. Llinás (eds.), Historia del derecho público. Bogotá: Ibáñez, pp. 413-456.

. (2016), "Ensayando la libertad. Reformas constitucionales y conflictos armados en perspectiva comparada, Brasil y Colombia (1821-1990)". In: B. Marquardt (ed.), Paz a través del derecho y de la Constitución. Anuario VI del Grupo de Investigación Constitucionalismo Comparado-CC. Bogotá: Ibáñez, pp. 141-168.

. (2010), As ideias de ordem social no Brasil e na Colômbia. Uma análise da casuística penal. Tese (Doutorado em Sociologia), Instituto Universitário de Pesquisas do Rio de Janeiro, Rio de Janeiro.

. (2006a), “Utilitarismo y tradicionalismo en la legislación penal republicana: el código de 1837". Revista Colombiana de Sociología [online]. n. 26. Disponível em: http:/ /www. revistas.unal.edu.co/index.php/recs/article/view/11383. ISSN electrónico 2256-5485. ISSN impreso 0120-159X. Acessado em 9 de setembro de 2019.

. (2006b), Racionalización formal y moralidad religiosa del derecho penal en la Nueva Granada: utilitarismo y tradicionalismo en el código penal neogranadino de 1837. Bogotá: Doctrina y Ley.

QUIJANO, Arturo. (1898), Ensayo sobre la evolución del derecho penal en Colombia. Bogotá: Imprenta y librería de Medardo Rivas.

RUSCHE, George; KIRCHHEIMER, Otto. (2004), Pena y estructura social. Bogotá: Temis.

SCHWARTZ, Richard D.; MILLER, James C. (1964), “Legal Evolution and Societal Complexity". American Journal of Sociology, n. 70, pp. 159.

SPITZER, Steven. (1975), "Punishment and social organization: a study of Durkheim's Theory of Penal Evolution". Law and Society Review, v. 9, n. 4, pp. 613-638. 
Aura Helena Peñas Felizzola e Gláucio Ary Dillon Soares

STONE, Alan. (1985), "The place of law in the marxian structure-superestructure archetype". Law and Society Review, v. 19, n. 1 pp. 39-68.

STUCKA, Petr. (1974), La función revolucionaria del Derecho y del Estado. Barcelona: Península.

TILLY, Charles. (2003), “Inequality, Democratization, and De-Democratization”. Sociological Theory, v. 21, n. 1 .

WEBER, Max. (1997), Economía y sociedad. México: Fondo de Cultura Económica.

WHITMAN, James. (2005), “The comparative study of criminal punishment”. Annual Review of Law and Social Science, v. 1, pp. 17-34.

ZAFFARONI, Eugenio R. (1994), Los códigos penales ibero-americanos. Bogotá: Forum Pacis. 


\section{RESUMO \\ Reformas Penais na Colômbia (1830-1940): Ideologias Políticas, Organização do Poder e Valores Sociais}

Este artigo analisa as tendências qualitativas e quantitativas na punição formal na Colômbia em quatro dos códigos penais aprovados entre 1830 e 1940 . O objetivo é explorar o poder explicativo de teorias sociais sobre as penas previstas nas leis, sendo elas: a) a de Durkheim, que atribui a maior severidade das punições ao predomínio da solidariedade mecânica e à maior concentração do poder político; b) a marxista, baseada na concepção do direito penal como ideologia da classe dominante; e c) as de Merton e Elias, que destacam a conexão existente entre a severidade das penas previstas na lei e as violências reais. Se conclui que o sistema penal busca impor ideias de ordem social que se configuram sobretudo através da política, mas que também recebem influências morais, religiosas e econômicas.

Palavras-chave: sociologia do direito penal; reforma penal; política penal; política criminal; criminologia

\section{ABSTRACT \\ Penal Reforms in Colombia (1830-1940): Political Ideologies, Power Organization, and Social Values}

This article analyzes the qualitative and quantitative trends in formal punishment in Colombia in four of the penal codes approved between 1830 and 1940. The aim is to explore the explanatory power of social theories about the punishments prescribed by the laws, namely: a) Durkheim's, which attributes the greater severity of punishments to the predominance of mechanical solidarity and the greater concentration of political power; b) the Marxist, based on the conception of criminal law as the ideology of the ruling class; and c) those of Merton and Elias, who highlight the connection between the severity of the punishments prescribed by the law and the actual violence. It is concluded that the penal system seeks to impose ideas of social order that are configured mainly through politics but also suffer moral, religious and economic influences.

Keywords: sociology of criminal law; penal reform; penal policy; criminal policy; criminology 


\section{RÉSUMÉ \\ Réformes pénales en Colombie (1830-1940): Idéologies Politiques, Organisation du Pouvoir et Valeurs Sociales}

Cet article analyse les tendances qualitatives et quantitatives des sanctions formelles en Colombie dans quatre des codes pénaux approuvés entre 1830 et 1940. L'objectif est d'explorer le pouvoir explicatif des théories sociales sur les sanctions prévues par la loi, à savoir: a) celle de Durkheim, qui attribue la plus grande sévérité des peines à la prédominance de la solidarité mécanique et à la plus grande concentration du pouvoir politique; b) le Marxiste, basé sur la conception du droit pénal comme idéologie de la classe dirigeante; et c) celles de Merton et Elias, qui mettent en évidence le lien entre la sévérité des peines prévues par la loi et la violence réelle. Il est conclu que le système pénal cherche à imposer des idées sociales qui sont configurées principalement par le biais de la politique, mais qui reçoivent également des influences morales, religieuses et économiques.

Mots-clés: sociologie du droit pénal; réforme pénale; politique pénale; politique criminale; criminologie

\section{RESUMEN}

Reformas Penales en Colombia (1830-1940): Ideologías Politicas, Organización del Poder y Valores Sociales

Este artículo analiza las tendencias cualitativas y cuantitativas en la sanción formal en Colombia en cuatro de los códigos penales aprobados entre 1830 y 1940. El objetivo es explorar el poder explicativo de teorías sociales sobre las penas previstas en las leyes, siendo estas: a) la de Durkheim, que atribuye la mayor severidad de las sanciones al predominio de la solidaridad mecánica y la mayor concentración del poder político; b) la marxista, basada en la concepción del derecho penal como ideología de la clase dominante; y c) las de Merton y Elias, que destacan la conexión existente entre la severidad de las penas previstas en la ley y las violencias reales. Se concluye que el sistema penal busca imponer ideas de orden social que se configuran principalmente a través de la política, pero que también reciben influencias morales, religiosas y económicas.

Palabras clave: sociología del derecho penal; reforma penal; política penal; política criminal; criminología 